\title{
POSTURAL COMPARISON BETWEEN A CONVENTIONAL BICYCLE HANDLEBAR AND AN ELLIPTICAL HANDLEBAR
}

\author{
COMPARAÇÃO POSTURAL ENTRE UM GUIDÃO CONVENCIONAL DE BICICLETAE UM GUIDÃO ELÍPTICO
}

POSTURAL COMPARATIVA ENTRE UN MANILLAR CONVENCIONAL DE BICICLETA Y UN MANILLAR ELIPTICO

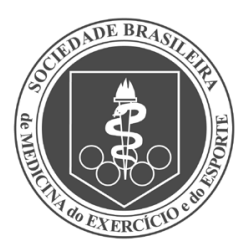

Original Article

Artigo Original Artículo Original
Luciana Almeida Chaebub

Rodrigues $^{1}$

(Medical student)

Maysa Venturoso Gongora

Buckeridge Serra ${ }^{1}$

(Physiotherapist)

Marina Germano de Souza Liporaci' (Medical student)

Renata Almeida Chaebub

Rodrigues $^{2}$

(Medical student)

Thaís Bertoco'

(Medical student)

Glaúcio Tasso de Carvalho Júnior (Medical student)

Maria Georgina Marques Tonello' (Physical Education Professional)

\section{Universidade de Franca (UNIFRAN), Franca, SP, Brazil. 2. Centro Universitário de Patos de Minas, Patos de Minas, MG, Brazil. 3. Universidade Federal do Triângulo Mineiro, Uberaba, MG, Brazil.}

\section{Correspondence:}

Luciana Almeida Chaebub Rodrigues

Capitão Florindo José da Silva Street, 499, Ituverava, SP, Brazil. 14500-000.

luth_chaib@hotmail.com

\begin{abstract}
Introduction: Cycling has been encouraged, not only as a way to reduce environmental pollution but also to improve people's health. For many, the bicycle is their sole form of transportation. In view of this growth, and potential risk of injury due to excessive bicycle use, an elliptical handlebar was developed with the purpose of modifying the hand and forearm grip and improving the rider's posture. Objective: To compare vertebral spine angulations with the use of conventional and elliptical handlebars. Methods: Twenty-six individuals participated in this study, in which they pedaled for two minutes with elliptical handlebars and two minutes with conventional handlebars, in order to compare the angulation of the vertebral spine using each type of handlebars. The images were filmed and evaluated by the Kinovea kinematic evaluation program. The statistical analysis was performed by Graphpad Prism 7. Results: It was observed that $88 \%$ of the participants had a more upright vertebral spine angulation when using the elliptical handlebar, with statistically significant difference $(p=0.0001)$. Conclusion: Bearing in mind that the handlebars were placed in similar support positions, it was observed, based on the quantified data, that the posture is more upright, and therefore more suitable, when using the elliptical handlebars. Level of Evidence Il; Diagnostic Studies - Investigating a Diagnostic Test.
\end{abstract}

Keywords: Posture; Bicycling; Spine.

\section{RESUMO}

Introdução: O ciclismo vem sendo incentivado, não apenas como forma de diminuir a poluição ambiental, mas também para melhorar a saúde das pessoas. Para muitos, a bicicleta é o único meio de transporte. Diante desse crescimento e do possível risco de lesões devido ao uso excessivo da bicicleta, foi desenvolvido um guidão elíptico com o propósito de modificar a empunhadura da mão e antebraço e melhorar a postura do ciclista. Objetivo: Comparar as angulações da coluna vertebral com o guidão convencional e o guidão elíptico. Métodos: Participaram deste estudo 26 indivíduos, que pedalaram por dois minutos com o guidão elíptico e dois minutos com o guidão convencional, a fim de comparar a angulação da coluna vertebral em cada tipo de guidão. As imagens foram filmadas e avaliadas pelo programa de avaliação cinemática Kinovea. A análise estatística foi realizada pelo programa Graphpad Prism 7. Resultados: Observou-se que $88 \%$ dos participantes obtiveram angulação da coluna vertebral mais ereta com o guidão elíptico, apresentando diferença estatisticamente significativa ( $p=0,0001$ ). Conclusão: Tendo em vista que os guidões foram colocados em posições similares de apoio, foi possivel observar, de acordo com os dados quantificados, que a postura é mais ereta e, portanto, mais adequada quando o guidão elíptico éusado. Nível de Evidência ll; Estudos Diagnósticos - Investigação de Teste Diagnóstico.

Descritores: Postura; Ciclismo; Coluna vertebral.

\section{RESUMEN}

Introducción: El ciclismo viene siendo incentivado, no sólo como forma de disminuir la contaminación ambiental, sino también para mejorar la salud de las personas. Para muchos, la bicicleta es el único medio de transporte. Ante este crecimiento y el posible riesgo de lesiones debido al uso excesivo de la bicicleta, se desarrolló un manillar elíptico con el propósito de modificar la empuñadura de la mano y antebrazo y mejorar la postura del ciclista. Objetivo: Comparar las angulaciones de la columna vertebral con el manillar convencional y el manillar elíptico. Métodos: Participaron de este estudio 26 individuos, que pedalearon por dos minutos con el manillar elíptico y dos minutos con el manillar convencional, a fin de comparar la angulación de la columna vertebral en cada tipo de manillar. Las imágenes fueron filmadas y evaluadas por el programa de evaluación cinemática Kinovea. El análisis estadístico fue realizado por el programa Graphpad Prism 7. Resultados: Se observó que el 88\% de los participantes obtuvieron la angulación de la columna vertebral más erecta con el manillar elíptico, presentando diferencia estadísticamente significativa ( $p=0,0001)$. Conclusión: Teniendo en cuenta que los manillares se colocaron en posiciones similares de apoyo, fue posible observar, de acuerdo con los datos cuantificados, una postura más erecta y, por lo tanto, más adecuada cuando se usa el manillar elíptico. Nivel de Evidencia Il. Estudios de Diagnóstico - Investigación de una Prueba de Diagnóstico.

Descriptores: Postura; Ciclismo; Columna vertebral. 


\section{INTRODUCTION}

There are people who use bicycle as a way of leisure, such as daily physical activity and, because they live in places far away from their work, they also use bicycle as transportation, which is supported by media and town halls for locomotion which does not pollute the environment. This transport is very important to benefit not only population health, but also the environment.'

Although cycling is a healthy transportation, its continuous and inadequate use (e. g. how conductor hold and supports handlebar) can lead to diseases such as ulnar nerve neuropathy, ${ }^{2}$ which occurs when person is pedaling for uninterrupted hours and manifest through pain, tingling, numbness and hand weakening through ulnar nerve, mainly reaching ring and minimal fingers; and carpal tunnel syndrome, ${ }^{3}$ which occurs by hand pressure on bicycles handlebar, leading to compression of tunnel where wrist flexor tendons and median nerve are located, being median nerve compression can cause pain, muscle atrophy and tingling in radial part of the hand ${ }^{4}$ among other pathologies.

Bicycle ergonomics is fundamental to its proper use. In this way, some adjustments are necessary according to conductor anthropometry so it isn't exposed to injuries. Ideally, conductor position should be comfortable during movement's development, as a bad positioning can bring injuries and premature fatigue during pedaling. ${ }^{5}$

Some studies ${ }^{6,7,8}$ show hand position on bicycle handlebar is decisive in injuries development caused by repetitive movements. Suggesting that a suitable and differentiated arrangement of bicycle handlebars can be created with aim of allowing users to use bicycle without major problems, such as an elliptical shaped handlebar fitted with gears and brakes, in place of conventional handlebars, which may reduce occurrence of hand injuries and back pain.

The design of elliptical handlebar, intended for ride-bicycles, aims to better adapt the user's posture to bicycle's dirigibility, in order to avoid back pain and an uncomfortable position that can, with prolonged use, cause spine damage. Correct pedaling posture, especially in children and young people, can avoid postural deviations and posture problems in the future. ${ }^{9}$

The first prototype of elliptical handlebar was created in 2004 from inventor's need to create a steering wheel for the bicycle, because the handlebars, how companies manufacture, caused back pain. To soften and eradicate pain caused by handlebar, inventor came to conclusion that an easily adjustable elliptical shaped handlebar could improve firmness and posture when pedaling. In 2005, the inventor registered the first patent application. In 2008, the first prototype of the new handlebar was built, which was placed on the streets. Design of this new type of handlebar was positive, because it caused peoples curiosity, who wanted to try it. The project was supported by Alltec Composites, which donated the carbon fiber for creation of the first prototype. (Figure 1)

Considering conventional handlebar only provides one position to hand support, it can be verified that, with prolonged use, cycling paralysis (injury hands of cyclists through ulnar nerve compression) becomes more frequent. ${ }^{2}$ The suggestion of a new handlebar device, in $360^{\circ}$ format, allows existence of various forms and positions for hand support, promoting different hand positions and possibly reducing the appearance of hand injuries caused by repetitive movements. ${ }^{4}$

The preferred bicycles by users are those who induce conductor a trunk upright stance, facilitating maintenance of a posture with spine flexion, without the discomfort that can cause pain in back and upper limbs. ${ }^{10}$

In this way, the aim of this study was to compare the vertebral spine angulation in two types of bicycle handlebars, conventional and elliptical handlebar.

\section{METHODS}

This study was approved by research ethics committee (CAAE: 62731016.3.0000.5495). Participant's selection of this study was a convenience sample; were selected 26 undergraduate students with previous experience in cycling. Inclusion criteria were individuals with no history of pathology in upper and lower limbs aged between 19 and 41 years. Before starting the tests, all participants agreed to participate in the study by signing Informed Consent Form.

Before tests were performed, anthropometric data (age, weight, height) of participants were collected. The body mass index (BMI) - mass ratio (kg) over height $(\mathrm{m})^{2}$ - was calculated from the mass and height values, which were measured using a balance and digital stadiometer (WISO - W $721^{\circledR}$ ). The BMI values were classified as: $<18.5 \mathrm{~kg} / \mathrm{m} 2$ (low weight); 18.5 to $24.9 \mathrm{~kg}$ / m2 (normal); 25 to 29.9 kg / m2 (overweight); and> $30 \mathrm{~kg} / \mathrm{m} 2$ (obesity). ${ }^{11}$

This was a cross-over study, which 26 individuals were evaluated for comparison between conventional handlebar and elliptical handlebar. Initially, each participant was instructed to pedal at a comfortable speed for two minutes with conventional handlebar and, posteriorly, for two minutes with elliptical handlebar, while the pedaling cycles were filmed for later evaluation. Bicycle was placed in an iron support that suspended rear wheel in order to pedal without leaving the place. The participants wore comfortable and tight clothing to the body so they do not interfere with tests performance and footage evaluation.

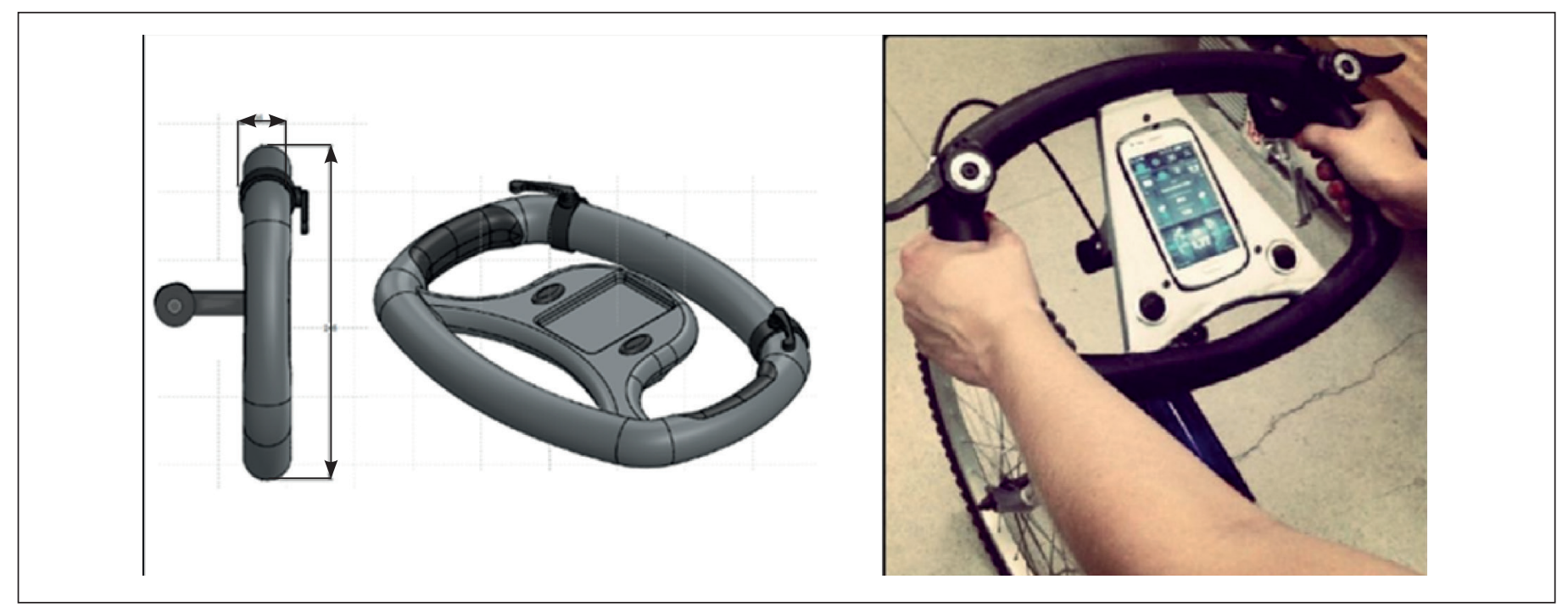

Figure 1. Prototype of elliptical handlebar. 
Four anatomical points were identified: point 1: seventh cervical vertebra (C7), point 2: sixth thoracic vertebra (T6), point 3: tenth thoracic vertebra (T10), point 4: fourth lumbar vertebra (L4). Passive markers were attached to participant skin with double-sided adhesive tape at each determined anatomic point, thus determining vertebral spine angulation. With these markers it was possible to obtain range of motion from vertebral spine positioning during pedaling cycle.

For two-dimensional analysis (2D) of pedaling was used a video camera (SONY DSC-W230) positioned to allow recording of lateral part of participant's body (sagittal plane) to monitor spine movement and upper left limb.

A complete pedaling cycle was selected with the tests of each handlebar (conventional and elliptical), and kinematic parameters of angular displacements between spine segments (points: 1,2,3,4) were evaluated. Figure 2 shows segment and angle evaluated.

For image processing and 2D analysis of the pedaling using each handlebar, computer program KINOVEA was used to measure angulation between specific segments. The mean and standard deviation of each participant's vertebral spine angulation were calculated individually. For statistical analysis, GraphPad Prism 7 program was used, using Kolmogorov Smirnov test, to verify normal distribution among domains. The Student's t-test was used to compare results who presented normal distribution. For data that did not present normal distribution the Mann-Whitney test was used, considering significant when $p<0.05$

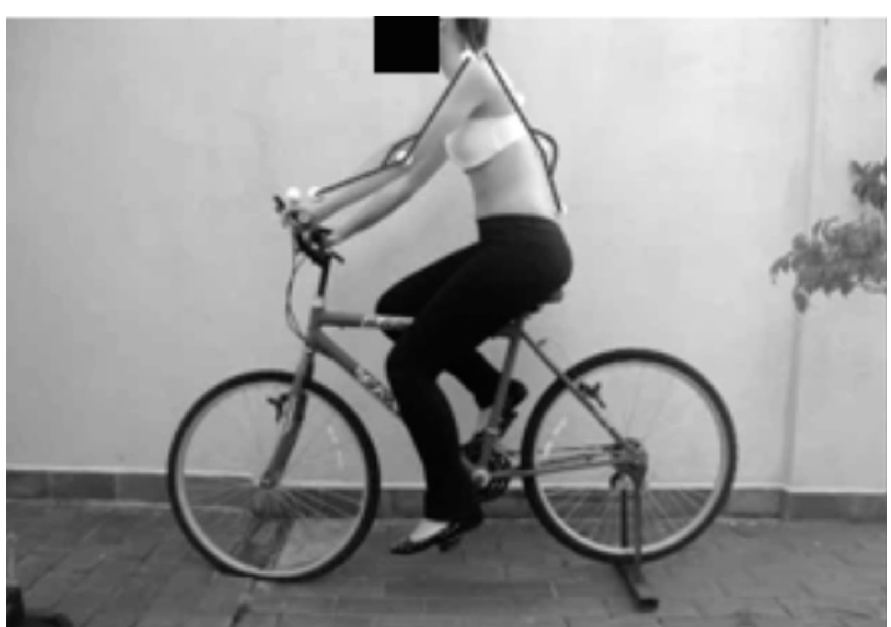

Figure 2. Vertebral spine angle (points: 1,2,3,4)

\section{RESULTS}

From collected data, a complete pedaling cycle of each participant was evaluated, obtaining mean values by KINOVEA program and comparing between two tested conditions (conventional handlebar and elliptical handlebar). Figure 3 shows angular variation of vertebral spine segments.

It was observed that 23 participants (88\%) obtained more upright vertebral spine angulation with elliptical handlebar $\left(200^{\circ} \pm 7\right)$ than conventional handlebar $\left(204^{\circ} \pm 8\right)$, presenting a statistically significant difference $(p=0.0001)$.

\section{DISCUSSION}

This study showed $88 \%$ of participants achieved a more upright posture with elliptical handlebar. Correct bicycle sizings, as well as upright or flexed trunk posture are essential for conductor comfort and prevention of cycling neuropathies. Dreyfuss's Theory ${ }^{10}$ reports a more upright posture causes a decrease in weight and pressure applied to hands and wrists by elbow slight flexion in which it can prevent cycling neuropathies caused in the hand region ${ }^{10}$ and confer a more appropriate posture. Therefore, it can be suggested, because elliptical handlebar presents,

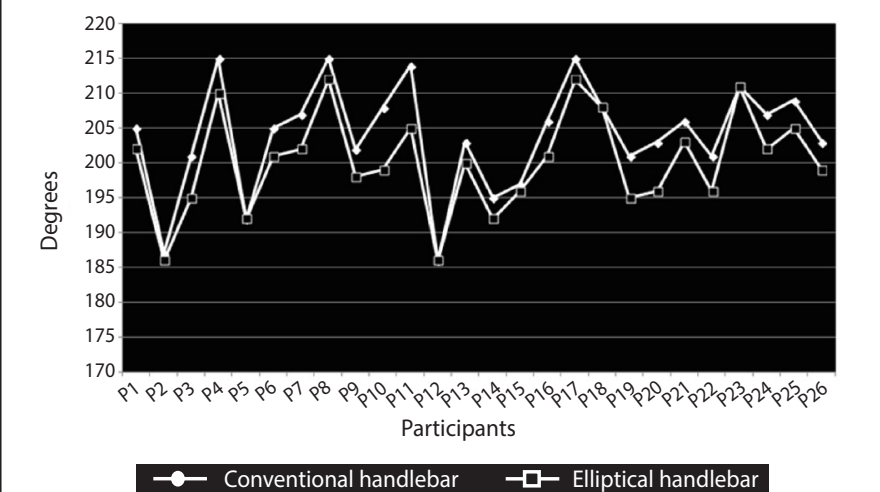

Figure 3. Comparison of vertebral spine angulations using conventional handlebar and elliptical handlebar.

in majority volunteers, a more upright position, it could be effective helping to prevent cyclist neuropathies in hand region and provides a more comfortable posture.

It's important to note that elliptical handlebar has been placed in same position as conventional handlebar. The angulation mean achieved in both handlebars was greater in conventional handlebar (203degrees) than elliptical handlebar (199 degrees). It is possible to observe that, considering the height of the individuals, the elliptical handlebar has a lower range of motion than conventional handlebar.

The elliptical handlebar allows different handle positions and gives to conductor option of making neutral hand position. Most conventional handlebar destined to ride-bicycles offer only one hand grip and in pronation, increasing chances of generating ulnar and medial nerve compression causing cycling paralysis. When subject makes a neutral hand position, reducing pressure applied in this region, he redistributes his weight throughout the body, acquiring a more adequate posture. ${ }^{4}$

In addition to body pressure applied on hands, it's believed wrist position affects both ulnar and middle nerves. ${ }^{12,13,14}$ An extended wrist posture may directly contribute to nervous tension. ${ }^{12}$ Studies shown wrist greatest extension was verified when cyclist has lowest hand position, which could exacerbate potential for nerve damage. ${ }^{4}$

Using a glove with upholstery can reduce the maximum pressure applied in hypothenar region by 10-20\%. However, pressure still is high and, with frequent use, can lead to hands impairment. Therefore, a change in grip position seems to be necessary to reduce risk of cycling paralysis during long-term pedaling. ${ }^{4}$

Hsiao et $\mathrm{al}^{15}$ found the bicycle posture that gives a more upright position was described as most comfortable during pedaling. This study considered competition bicycles and ride-bicycles, where it was reported hands position above saddle (ride-bicycles), gave more comfort to conductos in relation to bicycles that gave position of handle under the saddle. (bicycles of competition) ${ }^{15}$

The authors of previously pointed out study concluded the more lower positioning of handlebar, more cervical spine will be extended. Higher handlebars position, compared to handlebars positioned in competition bikes (lower), are more favorable to reduce load on cervico-thoracic spine segments. ${ }^{16}$ Therefore, it was proposed in this study, to increase conductor comfort, higher bicycle bars when considering curvatures of vertebral spine. ${ }^{17}$ Thus, because elliptical handlebar has different handle options, the participant can choose to hold handlebar that allows him to keep his arms closer to his body, which can give him a more upright posture, thus not generating hyperextension and discomfort in region cervical.

When a posture is performed with vertebral spine flexion, it can cause load increases, intervertebral disc pressure and lower 
back pain. ${ }^{18,19,20}$ In fact, lower back pain is one of the most common overuse injuries in cyclists, and it's related to constant act frequency of trunk flexing in the bicycle. ${ }^{21}$

Bicycle adjustment was not performed for each participant, since the aim was to simulate real situation of population majority which generally doesn't perform any type of adjustment when using bicycles, that may be standardized not only for a specific type of individual, and are available by city hall to some sections, thus verifying the effects of each handlebar on people using popular bikes without adjustments.

\section{CONCLUSION}

Elliptical handlebar gave participant of this study a more uprigth spine angulation than conventional handlebar. Considering that handlebars were placed in similar positions of support, it was possible to observe that, according to the quantified data, a more adequate posture is obtained when using elliptical handlebar.

All authors declare no potential conflict of interest related to this article

AUTHORS' CONTRIBUTIONS: Each author made significant individual contributions to this manuscript. LACR (0000-0001-9271-6003)*: writing the article, revision and performing the data collection; MVGBS (0000-0002-3576-5009)*: writing the article, revision, and data analysis; MGSL (0000-0002-6325-2892)*: data collection and revision of the article; RACR (0000-0001-6758-3165)*: data collection and revision of the article; TB (0000-0002-3125-3487)*: data collection and revision of the article; GTCJ (0000-0001-7842-2519)*: data collection and revision of the article; MGMT (0000-0002-8129-2177)*: writing and revision of the article. All authors approved the final version of the manuscript. ${ }^{*}$ ORCID (Open Researcher and Contributor ID).

\section{REFERENCES}

1. Shan G. Biomechanical evaluation of bike power saver. Appl Ergon. 2008;39(1):37-45

2. Brown CK, Stainsby B, Sovak, G. Guyon canal syndrome: lack of management in a case of unresolved handlebar palsy. J Can Chiropr Assoc. 2014;58(4):413-20.

3. Werner RA, Andary M. Carpal tunnel syndrome: pathophysiology and clinical neurophysiology. Clin Neurophysiol. 2002;113(9):1373-81.

4. Slane J, Timmerman M, Ploeg HL, Thelen DG. The influence of glove and hand position on pressure over the ulnar nerve during cycling. Clin Biomech (Bristol, Avon). 2011;26(6):642-8.

5. Korff T, Fletcher G, Brown D, Romer LM. Effect of "Pose" cycling on efficiency and pedaling mechanics. Eur J Appl Physiol. 2011;111(6):1177-86.

6. Christiaans HH, Bremner A. Comfort on bicycles and the validity of a commercial bicycle fitting system. Appl Ergon. 1998;29(3):201-11.

7. Sauer JL, Potter JJ, Weisshaar CL, Ploeg HL, Thelen DG. Biodynamics. Influence of gender, power, and hand position on pelvic motion during seated cycling. Med Sci Sports Exerc. 2007;39(12):2204-11.

8. Diefenthaeler F, Bini RR, Nabinger E, Laitano O, Carpes FP, Mota CB, et al. Proposta metodológica para a avaliação da técnica da pedalada de ciclistas: estudo de caso. Rev Bras Med Esporte. 2008;14(2):155-8.

9. Laios $L$, Giannatsis J. Ergonomic evaluation and redesign of children bicycles based on anthropometric data. Appl ergon. 2010;41(3):428-35.

10. Dreyfuss H. The measure of human factors in design. USA: ZND, 1966

11. Oreopoulos A, Padwal R, Zalantar-Zadeh K, Fonarow GC, Norris CM, MCAlister FA. Body mass index and mortality in heart failure: A meta-analysis. Am Heart J. 2008;156(1):13-22.
12. Carbone PO, Krause Neto W, Gama EF, Silva WA, Nobre TL, Caperuto EC, et al. Morphological adjustments of the radial nerve are intensity-dependent. Rev Bras Med Esporte. 2017;23(1):55-9.

13. Mogk JP, Keir PJ. Wrist and carpal tunnel size and shape measurements: effects of posture. Clin Biomech (Bristol, Avon). 2008;23(9):1112-20

14. Patterson JM, Jaggars MM, Boyer MI. Ulnar and median nerve palsy in longdistance cyclists. A prospective study. Am J Sports Med. 2003;31(4):585-9.

15. Hsiao SW, Chen RQ, Leng WL. Applying riding-posture optimization on bicycle frame design. App Ergon. 2015;51:69-79.

16. Kolehmainen I, Harms-Ringdahl K, Lanshammart H. Cervical spine positions and load moments during bicycling with different handlebar positions. Clin Biomech (Bristol, Avon). 1989;4(2):105-10

17. Chen YL, He KC. Changes in human cervical and lumbar spine curves while bicycling with different handlebar heights. Work. 2012;41(Suppl 1): 5826-7.

18. Sato K, Kikuchi S, Yonezawa T. In vivo intradiscal pressure measurement in healthy individuals and in patients with ongoing back problems. Spine (Phila Pa 1976). 1999;24(23):2468-74

19. Polga DJ, Beaubien BP, Kallemeier PM, Schelhas KP, Lew WD, Buttermann GR, et al. Measurement of in vivo intradiscal pressure in healthy thoracic intervertebral discs. Spine (Phila Pa 1976). 2004;29(12):1320-4.

20. Harrison DE, Colloca CJ, Harrison DD, Janik TJ, Haas JW, Keller TS. Anterior thoracic posture increases thoracolumbar disc loading. Eur Spine J. 2005;14(3):234-42.

21. Muyor JM. The influence of handlebar-hands position on spinal posture in professional cyclists. J Back Musculoskelet Rehabil. 2015;28(1):167-72. 